\title{
Calcium potentiates the effect of estradiol on PGF2a production in the bovine endometrium
}

\author{
Claudia Maria Bertan Membrive ${ }^{1}$, Pauline Martins da Cunha ${ }^{2}$, Flávio Vieira Meirelles ${ }^{3}$ and Mario Binelli ${ }^{*}$
}

\begin{abstract}
Background: Estradiol $\left(E_{2}\right)$ is required for luteolysis in cows and its injection stimulates prostaglandin F2a (PGF2a) release. The main goal of our study was to investigate the ability of endometrial explants and cells treated with $E_{2}$ and the calcium ionophore (CI) A23187 to synthesize PGF2a.

Results: Treatment with $E_{2}$ in vivo resulted in a $48.4 \%$ increase of PGF2a production by endometrial explants treated in vitro with A23187. Production of PGF2a was better stimulated with A23187 at concentrations of $10^{-6}$ and $10^{-5} \mathrm{~mol} / \mathrm{L}$ compared with other concentrations used. The concentration of PGF2a for untreated bovine endometrial cell cultures was $33.1 \mathrm{pg} / \mathrm{mL}$, while for cultures treated with $E_{2}, A 23187$, or a combination of $E_{2}$ and A23187, the PGF2a concentration was 32.5, 92.4 and $145.6 \mathrm{pg} / \mathrm{mL}$, respectively.
\end{abstract}

Conclusions: Treatment with A23187 tended to stimulate PGF2a production. In the presence of E2, A23187 significantly stimulated PGF2a synthesis. It appears that A23187 potentiates the effects of $E_{2}$ with respect to synthesis of endometrial PGF2a in cattle.

Keywords: Animal reproduction, Cattle, Estradiol, Luteolysis, PGF2a synthesis, Reproductive physiology

\section{Background}

In cattle, administration of $17 \beta$-estradiol (E2; $3 \mathrm{mg}$ ) as early as day 13 of the estrous cycle causes an increase in the plasma concentration of 13,14-dihydro-15-ketoprostaglandin F2 $\alpha$ (PGFM), the main metabolite of PGF2 $\alpha$ $[1,2]$. Consistently, ablation of ovarian follicles, which causes a decrease in plasma concentrations of $E_{2}$, delays luteolysis in ruminants [3-5]. $\mathrm{E}_{2}$ is capable of inducing endometrial synthesis of PGF $2 \alpha$ [6]; furthermore, $E_{2}$ can induce luteolysis [7].

The endometrial synthesis of PGF2 $\alpha$ results from a complex cascade of highly coordinated events. Arachidonic acid (AA), stored in the phospholipid membranes, is the primary precursor of prostaglandins [8]. Oxytocin (OT), acting through its receptor on the endometrial cell membrane, activates a guanosine nucleotide-binding protein (G protein), which promotes the activation of phospholipase C (PLC) [9]. PLC then cleaves phosphatidylinositol triphosphate into inositol triphosphate $\left(\mathrm{IP}_{3}\right)$ and diacylglycerol (DAG). $\mathrm{IP}_{3}$ binds to receptors on the endoplasmic reticulum,

\footnotetext{
* Correspondence: binelli@usp.br

${ }^{2}$ Department of Animal Reproduction, School of Veterinary Medicine and

Animal Science, University of São Paulo, São Paulo, Brazil

Full list of author information is available at the end of the article
}

promoting an increase in cytoplasmic calcium concentration. DAG activates protein kinase C (PKC), a serine/threonine kinase that is dependent on calcium for activation. Activated PKC phosphorylates phospholipase $\mathrm{A}_{2}\left(\mathrm{PLA}_{2}\right)$. The $\mathrm{IP}_{3}$-induced increase in cytosolic calcium stimulates calcium-dependent PLA $\mathrm{P}_{2}$ activity [10]. PLA 2 preferentially cleaves the sn- 2 position of phosphatidylcholine, releasing AA [11]. The free AA is then converted into prostaglandin $\mathrm{H}_{2}\left(\mathrm{PGH}_{2}\right)$ by prostaglandin endoperoxide synthase 2 (PTGS2). Finally, $\mathrm{PGH}_{2}$ is converted into PGF2 $\alpha$ by PGF synthases, such as Aldo-keto reductase family 1 member C1 (AKR1C1). Calcium is a known cofactor of PKC and $\mathrm{PLA}_{2}$, which are enzymes involved in PGF2 $\alpha$ production. Although the proteins involved in the synthesis of PGF $2 \alpha$ have been identified, the role of $E_{2}$ in this process remains unknown.

The main goal of our study was to determine the ability of endometrial explants and cells to synthesize PGF2 $\alpha$. Specifically, we sought to evaluate the capacity of $E_{2}$, when administered in vivo, to stimulate PGF2 $\alpha$ synthesis in endometrial explants incubated with a calcium ionophore (CI), melittin or oxytocin. We also sought to determine the $\mathrm{CI}$ dose that was capable of stimulating the synthesis of PGF2 $\alpha$ in cultured endometrial cells, and to evaluate 
the capacity of bovine endometrial (BEND) cells to synthesize PGF2 $\alpha$ following treatment with $\mathrm{E}_{2}$ and/or a CI.

\section{Methods \\ Experiment 1}

We used 13 cyclic cross-bred beef heifers (B. taurus $\times B$. indicus) in our study. Animals procedures were approved by Ethics and Animal Handling Committee of the Universidade de São Paulo. Animals were fed pasture (Brachiaria decumbens var. marandu) supplemented with minerals and had access to water ad libitum. Animals were implanted with a device containing $1 \mathrm{~g}$ of $\mathrm{P} 4$ (CIDR ${ }^{\circ}$, Pfizer, USA) along with an intramuscular injection of gonadorelin $\left(100 \mu \mathrm{g}\right.$; Fertagil ${ }^{\circ}$, Intervet, The Netherlands) on the first day of the synchronization protocol. Devices were removed 7 days later and cows were administered Dcloprostenol (150 $\mu \mathrm{g}$; Preloban ${ }^{\circ}$, Intervet) intramuscularly and were marked on the tailhead using an All-Weather Paintstik ${ }^{\circ}$ (LA-CO Industries Inc., USA). Estrous behavior was observed twice daily for $48-120$ h after PGF $\alpha \alpha$ was injected. The start of standing estrus was considered day 0 of the estrous cycle (day 0). On day 6, an ultrasonographic examination was performed (Aloka, SSD-500, linear probe $7.50 \mathrm{MHz}$ ), and females with a dominant follicle $\geq 7.5 \mathrm{~mm}$ received an intramuscular injection of gonadorelin $(100 \mu \mathrm{g}$; Fertagil $^{\circ}$, Intervet, The Netherlands) to induce ovulation of the dominant follicle and promote the emergence of a new follicular wave [12]. Ultrasonographic examination was performed to verify the presence of an accessory corpus luteum on day 16 of the cycle. Heifers were paired according to the day of standing estrus and randomly chosen for intravenous treatment with $0(n=6)$ or $3 \mathrm{mg}$ of $\mathrm{E}_{2}(n=7)$ on day 17 . At $2 \mathrm{~h}$ post-treatment, animals were stunned by cerebral concussion from a pneumatic pistol and euthanized by jugular exsanguination. Genital tracts were transported to our laboratory on ice immediately after animals were euthanized. The endometrium of the ipsilateral horn to the original corpus luteum was dissected, and fragments of the intercaruncular region weighing $80-100 \mathrm{mg}$ were conditioned in $12 \mathrm{~mm} \times 75 \mathrm{~mm}$ borosilicate tubes containing $0.5 \mathrm{~mL}$ Krebs-Hensleit bicarbonate medium (KHB; $118 \mathrm{mmol} / \mathrm{L} \mathrm{NaCl}, 4.7 \mathrm{mmol} / \mathrm{L}$ $\mathrm{KCl}, 2.56 \mathrm{mmol} / \mathrm{L} \mathrm{CaCl}, 1.13 \mathrm{mmol} / \mathrm{L} \mathrm{MgCl} 2,25 \mathrm{mmol} / \mathrm{L}$ $\mathrm{NaHCO}_{3}, 1.15 \mathrm{mmol} / \mathrm{L} \mathrm{NaH} \mathrm{PO}_{4}, 5.55 \mathrm{mmol} / \mathrm{L}$ glucose, $20 \mathrm{mmol} / \mathrm{L}$ Hepes and $0.013 \mathrm{mmol} / \mathrm{L}$ phenol red, $\mathrm{pH}$ 7.4). Cultures were maintained according to procedures described by Burns et al. [13]. Tubes containing explants were kept at $37^{\circ} \mathrm{C}$ in a shaking waterbath $(40 \mathrm{rpm})$ for $1 \mathrm{~h}$. Culture media was discarded and explants were washed twice with $0.5 \mathrm{~mL}$ of $\mathrm{KHB}$. Explants were incubated for $1 \mathrm{~h}$ in $\mathrm{KHB}$, washed, and then treated in vitro with $1 \mathrm{~mL}$ of either: KHB medium (control); KHB supplemented with $10^{-5} \mathrm{~mol} / \mathrm{L}$ A23817, a CI (C-7522, Sigma Chemicals, USA);
KHB supplemented with $10^{-5} \mathrm{~mol} / \mathrm{L}$ melittin $(\mathrm{M}-2272$, Sigma Chemicals, USA); or KHB supplemented with $10^{-6} \mathrm{~mol} / \mathrm{L}$ OT (O-6379, Sigma Chemicals, USA). Explants from each cow received all treatments in triplicate. The concentrations of drugs we used were based on those previously reported [13-15]. Samples comprising $100 \mu \mathrm{L}$ of culture medium were removed immediately after the administration of treatments (time 0) and 60 min later. Samples were stored at $-20^{\circ} \mathrm{C}$ until required. The concentration of PGF2 $\alpha$ ( $\mathrm{pg} / \mathrm{mL} / \mathrm{mg}$ of endometrial tissue) in the culture medium was measured using radio immuno assays as described by Danet-Desnoyers et al. [14]. Intraassay variation coefficients were 23.7 and $14.1 \%$, and the inter-assay coefficients were 23.4 and $13.1 \%$ for standards containing 250 and $1,000 \mathrm{pg} / \mathrm{mL}$ PGF $2 \alpha$, respectively.

\section{Experiment 2}

We obtained BEND cells [16] from the American Type Culture Collection (ATCC CRL-2398; USA). Cells were suspended in $4 \mathrm{~mL}$ of complete culture medium [40\% HAM F-12 (N6760, Sigma Chemicals, USA); 40\% minimal essential medium (MEM; M0643, Sigma Chemicals, USA); 200 IU/L insulin (I5500, Sigma Chemicals, USA); $10 \%(\mathrm{v} / \mathrm{v})$ fetal bovine serum (FBS; 10270-106, Gibco Life, USA); $10 \%(\mathrm{v} / \mathrm{v})$ equine serum (Nutricel, Brazil); and $1 \%(\mathrm{v} / \mathrm{v})$ antibiotic and antimycotic solution (A7292, Sigma Chemicals, USA)] and seeded in 6-well tissue culture plates (Corning Incorporated, USA). Cells were cultured at $38.5^{\circ} \mathrm{C} / 5 \% \mathrm{CO}_{2}$ until $90 \%$ confluent. Subsequently, cells were maintained in serum-free medium for $24 \mathrm{~h}$, washed twice in the same medium, and incubated for $12 \mathrm{~h}$ in $4 \mathrm{~mL}$ of serum-free medium supplemented with $0,10^{-7}$, $10^{-6}$ or $10^{-5} \mathrm{~mol} / \mathrm{L}$ A23817 (C-7522, Sigma Chemicals, USA) in triplicate wells. Samples of media $(500 \mu \mathrm{L})$ were collected immediately after the administration of treatments (time 0 ) and $12 \mathrm{~h}$ later. After sample collection at time 0 , the same volume of medium containing the specific treatment was replaced in culture wells. Samples were stored at $-20^{\circ} \mathrm{C}$ until required. Experiments were repeated three times; intra-assay variation coefficients were 13.2 and $18.8 \%$, and inter-assay variation coefficients were 10.3 and $22.0 \%$ for standards containing 250 and $1,000 \mathrm{pg} / \mathrm{mL} \mathrm{PGF} 2 \alpha$, respectively.

\section{Experiment 3}

We seeded BEND cells in 24-well plates $\left(4 \times 10^{4}\right.$ cells/well; Corning Incorporated) with $1.5 \mathrm{~mL}$ of complete culture medium. Cultures were incubated at $38.5^{\circ} \mathrm{C} / 5 \% \mathrm{CO}_{2}$ until cells were $90 \%$ confluent. Cells were then cultured in serum-free medium for $24 \mathrm{~h}$, washed twice with the same medium, and incubated for $12 \mathrm{~h}$ in serum-free medium supplemented with $10^{-13} \mathrm{~mol} / \mathrm{L} \mathrm{E}_{2}$ (E-8875, Sigma Chemicals, USA) and $10^{-6} \mathrm{~mol} / \mathrm{L} \mathrm{A} 23817$ (Sigma Chemicals, USA). Control wells received serum-free medium without 
supplements; all experiments were conducted in triplicate. Samples of media $(300 \mu \mathrm{L})$ were collected immediately after the administration of drugs (time 0 ) and $12 \mathrm{~h}$ later. After sample collection at time 0 , the same volume of medium containing the specific treatment was replaced in wells. Samples were stored at $-20^{\circ} \mathrm{C}$ until subsequent measurement of PGF2 $\alpha$ concentration. Experiments were conducted three times; intra-assay variation coefficients were 16.0 and $20.6 \%$, and the inter-assay variation coefficients were 4.0 and $18.9 \%$ for standards containing 250 and $1,000 \mathrm{pg} / \mathrm{mL} \mathrm{PGF} 2 \alpha$, respectively.

\section{Statistical analysis}

Data that did not meet the assumptions of normality of residues (Shapiro-Wilk Test, $P \leq 0.01$ ) or homogeneity of variances (F Test, $P \leq 0.01$ ) were transformed by square roots and reanalyzed. Data were analyzed by ANOVA using the GLM procedure with the SAS program and are presented as untransformed least squares means \pm SEM. Treatment means were compared by orthogonal contrasts. In Experiment 1, the dependent variable was DIF60 (the difference between PGF2 $\alpha$ concentrations at 0 and $60 \mathrm{~min}$ ), and the independent variable was treatment. For Experiments 2 and 3 the dependent variable was DIF12 (the difference between PGF2 $\alpha$ concentrations at 0 and $12 \mathrm{~h}$ ) and the independent variables were experiment, treatment and the interaction between experiment and treatment. Statistical significance was considered at $P<0.05$.

\section{Results}

\section{Experiment 1}

The DIF60 for the various treatments are shown in Table 1. Endometrial explants that remained untreated in vitro produced similar concentrations of PGF $2 \alpha$ whether they were obtained from cows injected with $E_{2}(3 \mathrm{mg})$ $(20.7 \pm 4.2 \mathrm{pg} / \mathrm{mL} / \mathrm{mg}$ of tissue $)$ or not $(24.7 \pm 4.6 \mathrm{pg} / \mathrm{mL} / \mathrm{mg}$ of tissue; Table 1). Regarding control animals, PGF2 $\alpha$ synthesis was similar among untreated explants $(24.7 \pm$ $4.6 \mathrm{pg} / \mathrm{mL} / \mathrm{mg}$ of tissue) and explants treated with OT $(28.2 \pm 4.6 \mathrm{pg} / \mathrm{mL} / \mathrm{mg}$ of tissue), melittin $(26.9 \pm$ $5.0 \mathrm{pg} / \mathrm{mL} / \mathrm{mg}$ of tissue) or A23187 $(29.0 \pm 4.6 \mathrm{pg} / \mathrm{mL} / \mathrm{mg}$

Table $\mathbf{1}$ Concentration of PGF2a (pg/mL/mg of tissue)
produced by endometrial explants from cross-bred
heifers on Day $\mathbf{1 7}$ of the estrous cycle treated in vivo
with $\mathbf{1 7} \boldsymbol{\beta}$-estradiol and in vitro with $\mathbf{A 2 3 8 1 7}$, melittin or OT
\begin{tabular}{lcccc}
\hline Variable & \multicolumn{4}{c}{ Treatment (mean \pm SEM) } \\
\cline { 2 - 5 } & Control & $\mathbf{E}_{\mathbf{2}}$ & Stimulator & $\mathbf{E}_{\mathbf{2}} /$ Stimulator \\
\hline DIF60 -A23817 & $24.7 \pm 4.6^{\mathrm{b}}$ & $20.7 \pm 4.2^{\mathrm{b}}$ & $29.0 \pm 4.6^{\mathrm{b}}$ & $43.0 \pm 4.2^{\mathrm{a}}$ \\
DIF60 - melittin & $24.7 \pm 4.6$ & $20.7 \pm 4.2$ & $26.9 \pm 5.0$ & $31.7 \pm 4.6$ \\
DIF60 - OT & $24.7 \pm 4.6$ & $20.7 \pm 4.2$ & $28.2 \pm 4.6$ & $33.2 \pm 4.2$
\end{tabular}

a,b significantly different, $P \leq 0.01$. of tissue; Table 1). In contrast, synthesis of PGF2 $\alpha$ from explants originating from animals treated with $E_{2}$ was 48.4\% greater following exposure to A23817 (43.0 \pm 4.2 $\mathrm{pg} / \mathrm{mL} / \mathrm{mg}$ of tissue) compared with explants from control animals $(29.0 \pm 4.6 \mathrm{pg} / \mathrm{mL} / \mathrm{mg}$ of tissue; $P \leq 0.01)$. Treatment with $\mathrm{E}_{2}$ in vivo did not affect the responses to melittin $(26.9 \pm 5.0$ vs. $31.7 \pm 4.6 \mathrm{pg} / \mathrm{mL} / \mathrm{mg}$ of tissue) or OT (28.2 \pm 4.6 vs. $33.2 \pm 4.2 \mathrm{pg} / \mathrm{mL} / \mathrm{mg}$ of tissue).

\section{Experiment 2}

We used A23187 at $10^{-7}, 10^{-6}$ and $10^{-5} \mathrm{~mol} / \mathrm{L}$, and these concentrations stimulated dose-dependent increase in PGF2 $\alpha$ production (Figure 1). A23187 stimulated the synthesis of PGF $2 \alpha$ in all treatment groups compared with that seen in the control group $(P \leq 0.01)$. The level of stimulation was greater when A23187 was used at $10^{-6}$ and $10^{-5} \mathrm{~mol} / \mathrm{L}$, in comparison with A23817 at $10^{-7} \mathrm{~mol} / \mathrm{L}$ $(P \leq 0.01)$. We did not observe a significant difference in stimulation levels between $10^{-6}$ and $10^{-5} \mathrm{~mol} / \mathrm{L} \mathrm{A} 23817$.

\section{Experiment 3}

Mean PGF2 $\alpha$ concentrations were 33.1, 32.5, 92.4 and $145.6 \mathrm{pg} / \mathrm{mL}$ (SEM: $21.8 \mathrm{pg} / \mathrm{mL}$ ) for untreated cells, cells treated with $E_{2}$, cells treated with A23817, and cells treated with $E_{2}$ and A23817, respectively (Figure 2). Production of PGF2 $\alpha$ was similar between cells treated with $\mathrm{E}_{2}$ and untreated cells. The cells treated with A23817 tended $(P \leq 0.08)$ to produce higher quantities of PGF $2 \alpha$ compared with cells treated with $\mathrm{E}_{2}$, or cells that were left untreated. The combination of $E_{2}$ and $A 23817$ stimulated greater synthesis of PGF $2 \alpha$ compared with the other treatments $(P<0.01)$. A23817 was responsible for a $179 \%$ increase in $\mathrm{PGF} 2 \alpha$ production relative to the control group. When A23817 was combined with $\mathrm{E}_{2}$, the production of PGF $2 \alpha$ increased by $340 \%$ compared with that in the control group.

\section{Discussion}

In Experiment 1, PGF2 $\alpha$ synthesis was not stimulated in the endometrial explants from cows treated with $E_{2}$ in vivo and received no treatment in vitro (Table 1). These results oppose those reported by Mann [17]. In contrast, Asselin et al. [18] and Xiao et al. [19] reported that the addition of $E_{2}$ to the culture medium was not able to stimulate the release of PGF $2 \alpha$. Because of the inconsistencies in the previously reported data, it was considered appropriate to administer $\mathrm{E}_{2}$ in vivo in this experiment. Previous reports indicated that the administration of $E_{2}$ could stimulate the production of PGFM in cows on days 13 [2,20,21], 17 [20-22], 18 [1,20,23] and 19 [21] of the estrous cycle. Bertan et al. [21] verified that $E_{2}$ promoted an increase in the plasma concentration of PGFM $4 \mathrm{~h}$ after injection; its concentration peaked within $6.5 \mathrm{~h}$ and returned to basal levels $9 \mathrm{~h}$ after 


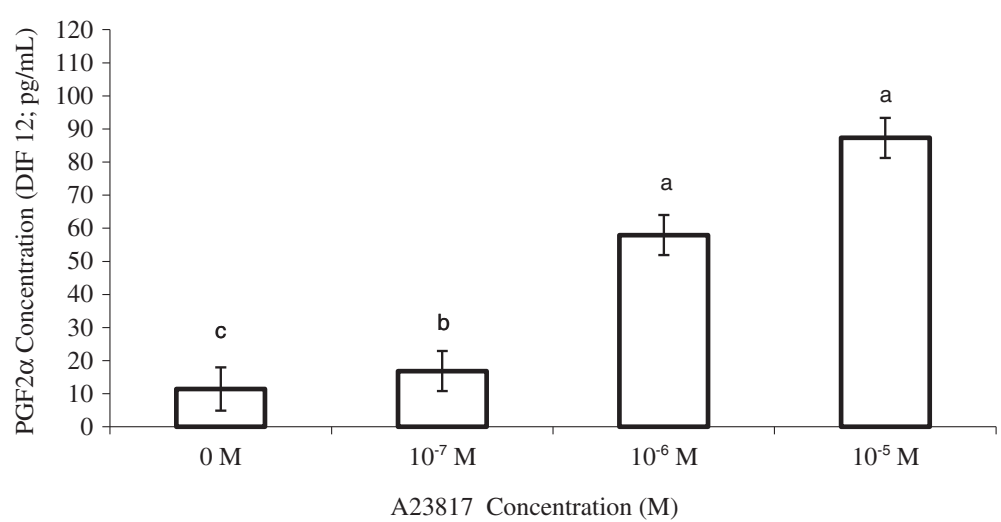

Figure 1 PGF2a production after $12 \mathrm{~h}$ in the culture medium of bovine endometrial (BEND) cells treated with A23817 (DIF12).

$a, b, c$ significantly different, $P<0.01$.

treatment. Given this time frame, it was considered appropriate to administer $\mathrm{E}_{2}$ in vivo $2 \mathrm{~h}$ prior to euthanizing cows. This procedure allowed the explants to be incubated with different stimulants approximately $6.5 \mathrm{~h}$ after the $\mathrm{E}_{2}$ injection.

It was expected that $E_{2}$ would stimulate the synthesis of enzymes involved in the synthesis of PGF2 $\alpha$. Thus, $E_{2}$ would increase the concentrations of the corresponding proteins in cellular compartments. It was also expected that the activity of these proteins during PGF $2 \alpha$ production would be amplified following specific stimulation. The CI A23817 promotes an increase in intracellular calcium concentration that is responsible for the activation of PKC and PLA2. The stimulant melittin specifically activates PLA2. Melittin and A23817 increase the synthesis of PGF2 $\alpha$ in ovine $[13,24]$ and bovine endometrial explants $[13,14,17,25,26]$; however, this stimulation was not observed in our studies when A23817, melittin or OT was used on their own.

In our Experiment 1, synthesis of PGF2 $\alpha$ was observed only when A23817 was used in combination with $E_{2}$. Other researchers observed that the effects of $E_{2}$ were frequently associated with an increase in the concentrations of free calcium in the cytosol [27-29]. We suggest that PKC and PLA2 are present in greater concentrations in the explants from animals treated in vivo with $E_{2}$. Increased production of PGF2 $\alpha$ would result in response to this greater concentration of enzymes stimulated by A23817. However, it is possible that higher concentrations of PLA2 in the endometrial explants that were previously exposed to $E_{2}$ could amplify the synthesis of PGF2 $\alpha$ in the presence of melittin. This could be explained by the fact that calcium is likely to be the major limiting factor in the activation of PLA2. In

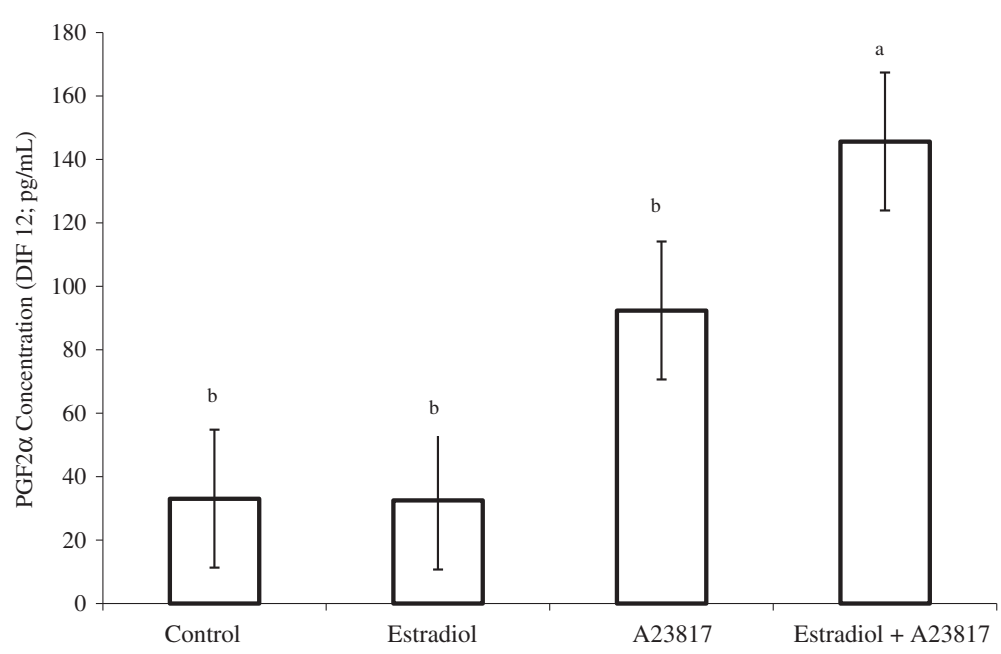

Figure 2 PGF2a production after $12 \mathrm{~h}$ in the culture medium of BEND cells treated with estradiol and/or A23817 (DIF12). ${ }^{a, b}$ significantly different, $P<0.01$. 
summary, we suggest that higher concentrations of PKC and PLA2 were present in the explants treated with $\mathrm{E}_{2}$, and that these enzymes promoted an increase in the synthesis of PGF2 $\alpha$ in the presence of A23817.

In Experiment 2 (Figure 1), A23817 stimulated the synthesis of PGF $2 \alpha$ for all treatment groups. When A23817 was administered at doses of $10^{-6}$ and $10^{-5} \mathrm{~mol} / \mathrm{L}$, stimulation was greater than that when the CI was used at $10^{-7} \mathrm{~mol} / \mathrm{L}$. The capacity of BEND cells to synthesize PGF2 $\alpha$ [30-32] and the cellular model for the synthesis of PGF2 $\alpha$ described by Burns et al. [13] indicate that calcium is responsible for the activation of enzymes such as PKC and PLA2. These enzymes are essential for the synthesis of PGF $2 \alpha$ by endometrial cells. Treatment with a CI has stimulated PGF2 $\alpha$ synthesis in endometrial explants from sows [33], guinea pigs [34,35], ewes [36-38] and cows $[14,15,39]$.

In our study, CI stimulated PGF2 $\alpha$ synthesis in BEND cells in a dose-dependent manner. Other studies have verified the dose-dependent effects of $\mathrm{CI}$ on the synthesis of PGF2 $\alpha$ in endometrial explants. Lafrance and Goff [40] observed that a CI at $2.6 \mu \mathrm{g} / \mathrm{mL}$ was sufficient to stimulate the synthesis of PGF2 $\alpha$ in the endometrial explants of heifers on days 19 or 20 of the estrous cycle. Danet-Desnoyers et al. [14] reported that the biosynthesis of PGF $2 \alpha$ stimulated by a CI in the endometrium of cows on day 17 of the estrous cycle exhibited a dosedependent response. Synthesis was increased by 0, 67 and $107 \%$ when doses of 2,4 and $10 \mu \mathrm{g} / \mathrm{mL}$ were administered, respectively. In the present experiment, doses of $0.052\left(10^{-7} \mathrm{~mol} / \mathrm{L}\right), 0.52\left(10^{-6} \mathrm{~mol} / \mathrm{L}\right)$, and $5.2 \mu \mathrm{g} / \mathrm{mL}$ $\left(10^{-5} \mathrm{~mol} / \mathrm{L}\right)$ increased the production of PGF $2 \alpha$ by 46 , 105 and $661 \%$, respectively. We propose that lower doses of A23817 stimulate the synthesis of PGF $2 \alpha$ in BEND cells, with a significantly amplified response compared with that in endometrial explants. The increase in intracellular calcium concentration is associated with PLA2 activity $[41,42]$ and in the increased availability of AA for the synthesis of PGF2 $\alpha$ [41]. Arnold et al. [15] verified that the synthesis of PGF $2 \alpha$ was stimulated in bovine endometrium cultured with a CI, regardless of whether it was supplemented with PLA2. Synthesis was greater when the endometrium was treated with a CI and PLA2 compared with explants treated with PLA2 alone. We propose that calcium has an additive effect on the stimulation of PLA2-induced synthesis of PGF2 $\alpha$.

Our hypothesis for Experiment 3 was that $E_{2}$ increases the sensitivity of endometrial cells to calcium. We verified that A23817 promoted an increase of $179 \%$ in the production of PGF $2 \alpha$ compared with untreated cells. However, when A23817 was used in combination with $E_{2}$, this increase was approximately $340 \%$ (Figure 2), similar to our results in Experiment 1. Thus, $\mathrm{E}_{2}$ increased the sensitivity of endometrial cells to calcium, supporting the hypothesis of our experiment. Several researchers reported that the synthesis of PGF $2 \alpha$ by endometrial explants was not increased by supplementing cultures with $\mathrm{E}_{2}[26,43,44]$. Consistently, in Experiment 3, synthesis of PGF2 $\alpha$ was not stimulated in BEND cells treated with $\mathrm{E}_{2}$ only. The genomic action of $E_{2}$ is promoted by the $E_{2}$-receptor complex, which activates transcription factors that are bound to DNA, ultimately resulting in new protein synthesis [29]. In vivo, $\mathrm{E}_{2}$ most likely activates the synthesis of PGF $2 \alpha$ by stimulating the transcription and translation of proteins involved in the production of PGF2 $\alpha$. However, the activity of $E_{2}$-induced proteins might need further stimulation in vitro because of limited access to calcium under culture conditions. In our study, the addition of A23817 to BEND cell cultures increased intracellular calcium concentrations, to enhance intracellular mechanisms that depend on this ion. Therefore, PKC and PLA2, which are involved in the synthesis of PGF $2 \alpha$, might have been activated, to increase synthesis of PGF $2 \alpha$.

In summary, from our experiments, $\mathrm{E}_{2}$ did not stimulate the synthesis of PGF2 $\alpha$ by endometrial cells and explants cultured in vitro. Many other in vitro studies have shown that the administration of $E_{2}$ alone in endometrial explants does not stimulate PGF2 $\alpha$ synthesis $[26,43,44]$. We suggest that the participation of $E_{2}$ in the synthesis of PGF2 $\alpha$ involves other endocrine and paracrine factors that are absent in cell and explant culture systems. Bertan et al. [21] clearly showed that $E_{2}$ did not immediately affect the cows that were treated on day 17 of the estrous cycle. The interval between the injection of $E_{2}$ and the increase in PGFM serum concentrations suggests that $E_{2}$ acts on the synthesis of PGF $2 \alpha$ through a genomic pathway. We speculate that $E_{2}$ directly stimulates the synthesis of proteins involved in PGF $2 \alpha$ production; these proteins might include PKC and PLA2, as they contain calciumdependent activation domains. Further studies are required to test this proposition.

\section{Competing interests}

The authors declare that they have no competing interests.

\section{Authors' contributions}

CMBM participated in the design of the study, in all experiments and drafted the manuscript. PMC participated in all experiments, FVM participated in in vitro experiments, and MB designed and coordinated the study. All authors read and approved the final manuscript.

\section{Acknowledgments}

This study was funded by Fundação de Amparo à Pesquisa do Estado de São Paulo (FAPESP). We are grateful to Professor William Thatcher from the University of Florida for antibodies against PGF2a.

\section{Author details}

1São Paulo State University, Rod. Comandante João Ribeiro de Barros (SP 294) Km 651, Dracena, SP 17900-000, Brazil. ²Department of Animal Reproduction, School of Veterinary Medicine and Animal Science, University of São Paulo, São Paulo, Brazil. ${ }^{3}$ Department of Veterinary Medicine, School of Animal Sciences and Food Engineering, University of São Paulo,

Pirassununga, Brazil. 
Received: 26 December 2013 Accepted: 29 April 2014

Published: 5 May 2014

\section{References}

1. Knickerbocker JJ, Thatcher WW, Foster DB, Wolfwnson D, Bartol FF, Caton D: Uterine prostaglandin and blood flow responses to estradiol-17 $\beta$ in cyclic cattle. Prostaglandins 1986, 31:757-770.

2. Thatcher WW, Terqui M, Thimonier J, Mauleon P: Effects of estradiol-17 $\beta$ on peripheral plasma concentration of 15-keto-13, 14-dihydro PGF2a and luteolysis in cyclic cattle. Prostaglandins 1986, 31(4):745-756.

3. Hughes TL, Villa-Godoy A, Kesner JS, Fogwell RL: Destruction of bovine ovarian follicles: effects on the pulsatile release of luteinizing hormone and prostaglandin F2a-induced luteal regression. Biol Reprod 1987 36:523-529.

4. Karsch FJ, Noveroske JW, Roche JF, Norton HW, Nalbandov AV: Maintenance of ovine corpora lutea in the absence of ovarian follicle. Endocrinology 1970, 87:1228-1236.

5. Villa-Goddoy A, Ireland JJ, Wortman JA, Ames NK, Hughes TL, Fogwell RL: Effect of ovarian follicles on luteal regression in heifers. J Anim Sci 1985, 60(2):519-527.

6. Hansel W, Alila HW, Dowd JP: Control of steroidogenesis in small and large bovine luteal cells. Aust J Biol Sci 1987, 40(3):331-347.

7. Auletta JF, Flint APF: Mechanisms controlling corpus luteum function in sheep, cows, non human primates and women, especially in relation to the time of luteolysis. Endocr Rev 1988, 9:88-105.

8. McCracken JA: Luteolysis a neuroendocrine-mediated event. Physiol Rev 1999, 79:263-323.

9. Burns PD, Hayes SH, Silvia WJ: Cellular mechanisms by which oxytocin mediates uterine prostaglandin F2 alpha synthesis in bovine endometrium: roles of calcium. Domest Anim Endocrinol 1998, 5:477-487.

10. Clark JD, Lin LL, Kriz RW, Ramesha CS, Sultzman LA, Lin AY, Milona N, Knop $J$ : A novel arachidonic acid-selective cytosolic PLA2 contains a $\mathrm{Ca}(2+)$ dependent translocation domain with homology to PKC and GAP. Cell 1991, 65:1043-1051.

11. Gijón MA, Leslie CC: Regulation of arachidonic acid release and cytosolic phospholipase A2 activation. J Leukoc Biol 1999, 65:330-336.

12. Diaz FJ, Anderson LE, Wu YL, Rabot A, Tsai SJ, Wiltbank MC: Regulation of progesterone and prostaglandin $\mathrm{F}_{2 a}$ production in the $\mathrm{CL}$. Mol Cell Endocrinol 2002, 191:65-68.

13. Burns PD, Graf GA, Hayes SH, Silvia WJ: Cellular mechanisms by which oxytocin stimulates uterine PGF2a alpha synthesis in bovine endometrium: roles of phospholipases $\mathrm{C}$ and A2. Domest Anim Endocrinol 1997, 14(3):181-191.

14. Danet-Desnoyers G, Meyer MD, Gross TS, Johnson JW, Thatcher WW: Regulation of endometrial prostaglandin synthesis during early pregnancy in cattle: effects of phospholipase and calcium in vitro. Prostaglandins 1995, 50:313-330.

15. Arnold DR, Binelli M, Vonk J, Alexenko AP, Drost M, Wilcox CJ, Thatcher WW: Intracellular regulation of endometrial PGF2 $a$ and $\mathrm{PGE}_{2}$ production in dairy cows during early pregnancy and following treatment with recombinant interferon-t. Domest Anim Endocrinol 2000, 18:199-216.

16. Staggs KL, Austin KJ, Johnson GA, Teixeira MG, Talbot CT, Dooley VA Hansen TR: Complex induction of bovine uterine proteins by interferon- $\tau$. Biol Reprod 1998, 59:277-283.

17. Mann GE: Hormone control of prostaglandin F2a production and oxytocin receptor concentrations in bovine endometrium in explant culture. Domest Anim Endocrinol 2001, 20:217-226.

18. Asselin $E$, Goff AK, Bergeron $H$, Fortier MA: Influence of sex steroids on the production of prostaglandin $\mathrm{F} 2 \mathrm{a}$ and $\mathrm{E}_{2}$ and response to oxytocin in cultured epithelial and stromal cells of bovine endometrium. Biol Reprod 1996, 54:371-379.

19. Xiao CW, Goff AK: Hormonal regulation of estrogen and progesterone receptors in cultured bovine endometrial cells. J Reprod Fertil 1999, 115:101-109.

20. Bertholazzi A, Bertan JP, Paula LA C e, Da Cunha PM, Loureiro JGP, Teixeira AB, Barros CM, Binelli M: Efeitos do benzoato de estradiol (EB) e cipionato de estradiol (ECP) na liberação de prostaglandina F2a (PGF2a) embovinos. In Proceedings of the Congresso de Integração em Biologia da Reprodução: 12-15 April 2003; Ribeirão Preto, Brazil. Edited by Alzira Amélia Rosa e Sllva: Arte Ciência Vilipress; 2003:307.
21. Bertan CM: Mecanismos endócrinos e moleculares pelos quais o estradiol estimula a síntese de prostaglandina F2a no endométrio de fêmeas bovinas. São Paulo: Tese (Doutorado em Reprodução Animal) Faculdade de MedicinaVeterinária e Zootecnia, Universidade de São Paulo; 2004:180

22. Jorge $P$, Bertan CM, Bertholazzi A, Paula LA C e, Da Cunha PM, Goissis M Bressan FF, Madureira EH, Binelli M: Efeitos Da Associação do 17ß-estradiol $\left(E_{2}\right)$ com o hormônioliberador de gonadotrofinas $(\mathrm{GnRH})$ e com gonadotrofina coriônica humana ( $\mathrm{hCG}$ ) na liberação de prostaglandina $\mathrm{F}_{2 a}$ (PGF2a) embovinos. In Congresso de Integração em Biologia da Reprodução: 12-15 April 2003; Ribeirão Preto, Brazil. Edited by Alzira Amélia Rosa e Sllva: Arte Ciência Vilipress; 2003:305.

23. Rico LW, Thatcher WW, Drost M, Wolfeenson D, Terqui M: Plasma PGFM responses to estradiol injection in pregnant and cycling cows. J Anim Sci 1981, 53(Suppl 1):363.

24. Lee JS, Silvia WJ: Cellular mechanisms mediating the stimulation of ovine endometrial secretion of prostaglandin $\mathrm{F} 2 \mathrm{a}$ in response to oxytocin: role of phospholipase A2. J Endocrinol 1994, 141:491-496.

25. Burns PD, Hayes SH, Silvia WJ: Cellular mechanisms by which oxytocin mediates uterine prostaglandin F2a synthesis in bovine endometrium: role of calcium. Domest Anim Endocrinol 1998, 15(6):477-487.

26. Skarzynski D, Bogacki M, Kotwica J: Involvement of ovarian steroids in basal and oxytocin-stimulated prostaglandin F2a secretion from bovine endometrium in vitro. Theriogenology 1999, 52:385-397.

27. Pietras RJ, Szego CM: Endometrial cell calcium and oestrogen action. Nature 1975, 253:357-359.

28. Stefano GB, Cadet P, Breton C, Goumon Y, Prevot V, Dessaint JP, Beauvillain JC, Roumier AS, Welters I, Salzet M: Estradiol-stimulated nitric oxide release in human granulocytes is dependent on intracellular calcium transients: evidence of a cell surface estrogen receptor. Blood 2000, 95:3951-3958

29. Acconcia F, Marino M: Synergism between genomic and non genomic estrogen action mechanism. IUBMB Life 2003, 55(3):145-150.

30. Binelli M, Guzeloglu A, Badinga L, Arnold DR, Sirois J, Hansen TR, Thatcher WW: Interferon-t modulates phorbol Ester-induced production of prostaglandin and expression of cyclooxygenase- 2 and phospholipase- 2 from bovine endometrial cells. Biol Reprod 2000, 63:417-424.

31. Guzeloglu A, Binelli M, Badinga L, Hansen TR, Thatcher WW: Inhibition of phorbol ester-induced PGF2a secretion by IFN-T is not through regulation of protein kinase C. Prostaglandins 2004, 74:87-99.

32. Guzeloglu A, Michel A, Michel F, Thatcher WW: Differential effects of interferon- $\tau$ on the prostaglandin synthetic pathway in bovine endometrial cells treated with phorbol ester. J Dairy Sci 2004, 87:2032-2041.

33. Basha SMM, Bazer FW, Roberts RM: Effect of the conceptus on quantitative and qualitative aspects of uterine secretion in pigs. $J$ Reprod Fertil 1980, 60:41.

34. Poyser NL: Effects of various factors on prostaglandin synthesis by the guinea-pig uterus. J Reprod Fertil 1987, 141:491-496.

35. Riley SC, Poyser NL: Prostaglandin production by the guinea-pig endometrium: is calcium necessary? J Endocrinol 1987, 113:463-472.

36. Silvia WJ, Homanics GE: Role of phospholipase $C$ in mediating oxytocin-induced release of prostaglandin F2 alpha from ovine endometrial tissue. Prostaglandins 1988, 35:535-548.

37. Raw RE, Silvia WJ, Curry TE: Effects of progesterone and estradiol on prostaglandin endoperoxide sythase in ovine endometrial tissue. Anim Reprod Sci 1995, 40:17-30.

38. Silvia WJ, Lewis GS, Mccracken JA, Thatcher WW, Jr W: L:Hormonal regulation of uterine secretion of PGF2a during luteolysis in ruminants. Biol Reprod 1991, 45:655-663.

39. Tysseling KA, Thaycher WW, Bazer FW, Hansen PJ, Mirando MA: Mechanisms regulating prostaglandin F2a secretion from the bovine endometrium. J Dairy Sci 1998, 81:382-389.

40. Lafrance $M$, Goff AK: Effects of $P_{4}$ and estradiol 17- $\beta$ on oxytocin induced releasing of prostaglandin F2a in heifers. J Reprod Fertil 1988, 82:429-436.

41. Van den Bosh H: Intracellular phospholipases. Biochem Biophys 1980 604:191-199.

42. Ho AK, Klein DC: Activation of alpha 1-adrenoreceptors, protein kinase $C$, or treatment with intracellular free $\mathrm{Ca}^{+2}$ elevating agents increases pineal phospholipase $A_{2}$ activity. J Biol Chem 1987, 262:11764-11769. 
43. Paula LA C e, Loreiro JGP, Membrive CMB, Da Cunha PM, Bertholazi A, Jorge $P$, Madureira EH, Binelli M: Effects of estradiol-17 $\beta$ on prostagandin F2a (PGF) secretion in cattle: in vitro and in vivo responses. Biol Reprod 2002, 66(Suppl 01):324.

44. Raw RE, Silvia WJ: Activity of phospholipase $C$ and release of prostaglandin F2a by endometrial tissue from ovariectomized ewes receiving progesterone and estradiol. Biol Reprod 1991, 44:404-412.

doi:10.1186/2049-1891-5-25

Cite this article as: Bertan Membrive et al: Calcium potentiates the effect of estradiol on PGF2a production in the bovine endometrium. Journal of Animal Science and Biotechnology 2014 5:25.

\section{Submit your next manuscript to BioMed Central and take full advantage of:}

- Convenient online submission

- Thorough peer review

- No space constraints or color figure charges

- Immediate publication on acceptance

- Inclusion in PubMed, CAS, Scopus and Google Scholar

- Research which is freely available for redistribution 